\title{
Influence of light and competition on crown and shoot morphological parameters of Norway spruce and silver fir saplings
}

\author{
Giacomo GRASSI $^{\mathrm{a}, \mathrm{b} *}$, Raffaello GIANNINI ${ }^{\mathrm{c}}$ \\ a Dip. Colture Arboree, University of Bologna, Via Fanin 46, 40127 Bologna, Italy \\ b Present address: University of Padua, Dip. Territorio e Sistemi Agro-Forestali, 35020 Legnaro (PD), Italy \\ ${ }^{c}$ Dip. Scienze e Tecnologie Ambientali Forestali, University of Florence, Italy
}

(Received 20 October 2003; accepted 17 December 2004)

\begin{abstract}
The effects of a natural gradient of light and competition on crown, shoot and needle morphology of naturally regenerated Norway spruce (Picea abies) and silver fir (Abies alba) saplings, 0.8-0.2 m tall, were analyzed in a uneven-aged, managed stand in Comelico (eastern Italian Alps). The results indicate that: (i) both crown, shoot and needle morphology are strongly affected by light, but in the examined conditions (relative irradiance ranging from 2 to $32 \%$ ) no significant effect of competition was observed, (ii) the ecological differences between Norway spruce and silver fir saplings cannot be mainly attributable to differences in crown morphological traits, and (iii) the apical dominance ratio (i.e., the length of the apical leader divided by the mean length of the lateral shoots at the last node) is a relatively good and simple indicator of the light conditions in which saplings are growing. These informations may be useful in order to promote and assure effectively natural regeneration.
\end{abstract}

light / competition / growth / crown morphology / shoot morphology

Résumé - Influence de la lumière et de la compétition sur les paramètres morphologiques de la couronne et de la pousse chez des plants d'épicéa et de sapin pectiné. Les effets d'un gradient naturel de lumière et de compétition sur la couronne, la pousse et la morphologie des aiguilles de plants $(0,8$ à $2,2 \mathrm{~m}$ de hauteur) d'épicéa (Picea abies) et de sapin pectiné (Apies alba) ont été analysés dans un peuplement inéquienne aménagé à Comelico (Est des Alpes Italiennes). Les résultats obtenus montrent que : (i) couronne, pousse et morphologie des aiguilles sont fortement affectées par la lumière, mais dans les conditions étudiées (éclairement relatif variant de 2 à $32 \%$ ) il n'a pas été observé d'effet significatif de la compétition ; (ii) les différences écologiques entre les plants d'épicéa et de sapin pectiné ne peuvent pas être attribuées principalement à des différences dans les caractéristiques morphologiques de la couronne ; (iii) le ratio de dominance apicale (i.e., longueur de la pousse terminale de la flèche divisée par la longueur moyenne des pousses latérales du dernier verticille) est relativement un bon et simple index des conditions de lumière dans lesquelles poussent les plans. Cette information peut être utile pour promouvoir et assurer efficacement une régénération naturelle.

lumière / compétition / croissance / morphologie de la couronne / morphologie de la pousse

\section{INTRODUCTION}

Crown, shoot and needle morphology have a critical influence on the light use efficiency and thus on the growth and competitive ability of understory saplings $[4,5,12,19,21]$. Therefore, understanding how these traits vary in relation to interacting factors is important in order to promote and assure effectively natural regeneration [1]. Several studies have shown that the effect of light on crown, shoot and needle morphology differs among tree species, with shade-tolerant species typically showing greater morphological changes along a light gradient than do the more shade-intolerant species $[4,7,8,12$,
33]. At the whole plant level, interspecific differences reflect alternative choices between height growth for future gain and investment for survival at present height [32]. In shade-tolerant conifers, for example, crown morphology typically varies from a conical form in full light to a flat-topped (or "umbrellashaped") form in the understory shade [26, 27]. This response is an adaptive choice to avoid self-shading within the same individual crown [17]. However, the relationships between light and growth or morphological parameters are far to be fully understood. Other than to be species-specific, for a certain species these relationships may vary among climatic regions [34] and may be greatly affected by the interaction with other factors

* Corresponding author: grassi@agrsci.unibo.it 
such nutrient availability, sapling size and competition $[8,10$, 16, 25, 31-33]. This complexity becomes especially relevant in uneven-aged managed forests, where the high structural fragmentation of the canopy and the clustering pattern of natural regeneration [15] lead to a high spatial variability of light in the understory and of competition between saplings.

An example of the difficulty to understand the effects of subtle differences in crown and shoot morphology on the response to light intensity is given by firs and spruces. Firs in general are considered to have a higher ability to maintain a positive carbon balance at low light intensities than spruces [1, 18, 21, 32]. This difference has been primarily attributed to a higher morphological plasticity in relation to light [21]. At the same time, at least at the foliar level, also physiological characters (i.e., photosynthetic capacity) were found to be important in explaining differences between firs and spruce [13]. However, foliar-level traits alone often do not explain the ecological performance of a species in different environments [12, 19]. Indeed, species partitioning among different light environments is often the result of small but effective differences in both physiological, morphological and allocation traits, both at the foliar and the whole-plant level [22].

Furthermore, understanding the effects of environmental factors on crown morphology is important also to develop reliable and easy-to-measure indicators of sapling vigour. Such empirically-derived relationships are strongly needed to better evaluate the effects of different silvicultural practices on the growth of natural regeneration [10].

The objectives of the present study are: (i) to assess the effects of light and competition on growth and on morphological parameters of Norway spruce (Picea abies Karst.) and silver fir (Abies alba Miller) natural regenerated saplings; (ii) test the hyphothesis that the different ecological performances between Norway spruce and silver fir saplings may reflect, at least in part, differences in crown or shoot morphological traits; and (iii) find a reliable and easy-to-measure indicator of sapling vigor in relation to light.

\section{MATERIALS AND METHODS}

The study was carried out in a uneven-aged and mixed (Picea abies and Abies alba) montane stand in the Comelico area $\left(46^{\circ} 38^{\prime} \mathrm{N}\right.$; $12^{\circ} 32^{\prime}$ E, Veneto Region), at $1400-1450 \mathrm{~m}$ asl. The average annual rainfall of this area ranges from 1100 to $1500 \mathrm{~mm}$, with a maximum in summer-autumn and minimum during the winter; the average temperature ranges from $16{ }^{\circ} \mathrm{C}$ (July) to $-3{ }^{\circ} \mathrm{C}$ (January) at $1300 \mathrm{~m}$ asl and from $13{ }^{\circ} \mathrm{C}$ (July) to $-5{ }^{\circ} \mathrm{C}$ (January) at $1900 \mathrm{~m}$ asl. Stands in Comelico are managed through a silvicultural system ranging from single-tree selection cutting to irregular group shelterwood, which leads to irregular spatial distribution of the tree crowns even at small scales [3]. The stand examined in this study can be described as "Abietetum on silicate soils" [9]. Norway spruce and silver fir saplings account for $70 \%$ and $30 \%$ of natural regeneration, respectively [14], roughly mirroring the composition of the overstory. Herbaceous and shrub vegetation is present where sufficient light is available in the understory, the main species being Oxalis acetosella, Carex spp., Ranunculus spp., Fragaria vesca, Vaccinium spp. and Brachipodium pinnatum.

The effects of light level and competition on growth and on crown and shoot morphological parameters were assessed for 76 saplings (48 Norway spruce and 28 silver fir), growing under a natural gradient of light availability and sapling density and randomly chosen between those having healthy leaders. Since many A. alba saplings were damaged by the fauna, it was not possible to have a uniform sample for both species. Saplings ranged between 0.8 and $2.2 \mathrm{~m}$ in height and between 1.8 and $4.5 \mathrm{~cm}$ in diameter in both species.

Photosynthetic photon flux density (PPFD) at the apical leader of 30 Norway spruce and 21 silver fir saplings was measured using quantum sensors (18 were SPK 215 from Skye Instruments, UK; 33 were self-assembled NPN silicon phototransistor P800 TRW Optron, previously calibrated against the Skye sensors). Each sensor, oriented horizontally, was firmly positioned adjacent to the apical leader of each selected sapling and connected to a portable datalogger (CR10, Campbell Scientific, UT, USA). Data were collected at 1-min intervals, from 7.00 to 17.00 , on 10 different days selected at the beginning, middle and end of the growing season on both clear and overcast sky conditions in order to increase their representativeness [11]. Another quantum sensor was positioned in a completely open, nearby site, in order to measure PPFD continuously for the whole growing season. In other 18 Norway spruce and 7 silver fir saplings, PPFD at the apical leader was estimated with fish-eye hemispherical photographs. These photographs were analyzed with the program Winphot for the same days in which quantum sensors were operating, taking into account the relative cloud cover of each days. Relative irradiance was calculated as ratio of PPFD at each sensor, or the PPFD estimated from photographs, to PPFD incident above the canopy for the same period.

Competition was assessed according to Duchesneau [10], i.e., by calculating a "competition index" among saplings which considers only competing individuals located in circular area (1.13 m radius) surrounding each selected sapling. The circular area was divided into four quadrants, and the competition index $(I)$ calculated as follows:

$$
I=\frac{1}{H_{\mathrm{s}}} \times \frac{1}{4} \sum_{J=1}^{4} \frac{C_{\mathrm{j}} H_{\mathrm{j}}}{D_{\mathrm{j}}},
$$

where $H_{\mathrm{s}}$ is the total height of the selected sapling, $C_{\mathrm{j}}$ the percent surface covered by competing saplings in quadrant $j, H_{\mathrm{j}}$ the mean height of competing saplings in quadrant $j$, and $D_{\mathrm{j}}$ the mean distance between the competing saplings in quadrant $j$ and the sample tree.

In all the sapling, growth was assessed by the relative height growth (RHG, length of the apical leader divided by total sapling height). Crown morphology was assessed by calculating the apical dominance ratio (ADR, length of the apical leader divided by the mean length of the healthy lateral shoots at the last node) and the percent live crown ratio (LCR, live crown depth divided by total height). RHG and ADR were calculated for each of the last five years. Furthermore, in the saplings in which PPFD was measured with quantum sensors (51 in total), shoot and needle morphology were characterized, respectively, by the ratio of total projected needle area to maximum shoot silhouette area (TPA/SSA, [30]) and by the leaf mass per area (LMA, $\mathrm{g} \mathrm{m}^{-2}$ ). Each shoot, taken from a lateral branch, was illuminated and photographed perpendicularly to the shoot axis and its maximum silhouette projected area (SSA) measured with a Hewlett Packard Scan-Jet 6300c scanner and Jandel Sigma Scan Pro V2.0 software. Then, the shoots were stripped of all the needles. After measurements of their total projected needle area (TPA), needles were oven-dried to constant weight to obtain the LMA. The SSA is a measure of maximum light interception by the shoot in direct-beam radiation, whereas the TPA measures the maximum (one-sided) surface that might be illuminated by directbeam radiation.

The relationships between the measured parameters were analyzed using non-linear functions of Table Curve 2d software (SPSS Inc.); the coefficient of determination $\left(r^{2}\right)$, the statistical significance of the regression $(P)$ and the $95 \%$ confidence limits were also calculated. 
Table I. Correlation coefficients among relative irradiance and the examined variables.

\begin{tabular}{lcc}
\hline Variables & Abies alba & Picea abies \\
\hline $\begin{array}{l}\text { Relative irradiance, competition } \\
\text { index }\end{array}$ & 0.62 & 0.54 \\
Relative irradiance, RHG & 0.74 & 0.65 \\
Relative irradiance, ADR & 0.74 & 0.70 \\
Relative irradiance, LCR & 0.68 & 0.62 \\
Relative irradiance, TPA/SSA & 0.72 & 0.77 \\
Relative irradiance, LMA & 0.83 & 0.74 \\
\hline
\end{tabular}

\section{RESULTS AND DISCUSSION}

A positive correlation between relative irradiance and competition index was found in both Norway spruce and silver fir (Fig. 1 and Tab. I). Although this correlation does not imply causation, it is reasonable to hypothesize that more light, by promoting higher photosynthetic rates and higher soil decomposition rates (i.e., more nutrients), allows more saplings to survive per unit of ground area than in the shaded understory.

In both examined species irradiance promoted a higher relative height growth (RHG, Fig. 2A and Tab. I), a higher apical dominance ratio (ADR) and a deeper live crown (LCR) (Figs. 3A, 3B and Tab. I), a higher total projected needle area to maximum shoot silhouette area (TPA/SSA) and a higher leaf mass per area (LMA) (Figs. 4A, 4B and Tab. I). In all these cases, a logarithmic regression explained better the relationship than a simple linear regression. Furthermore, for all the examined parameters, the $95 \%$ confidence limits of the regressions for Norway spruce and silver fir largely overlapped (data not shown), indicating no significant difference between species $(P>0.05)$.

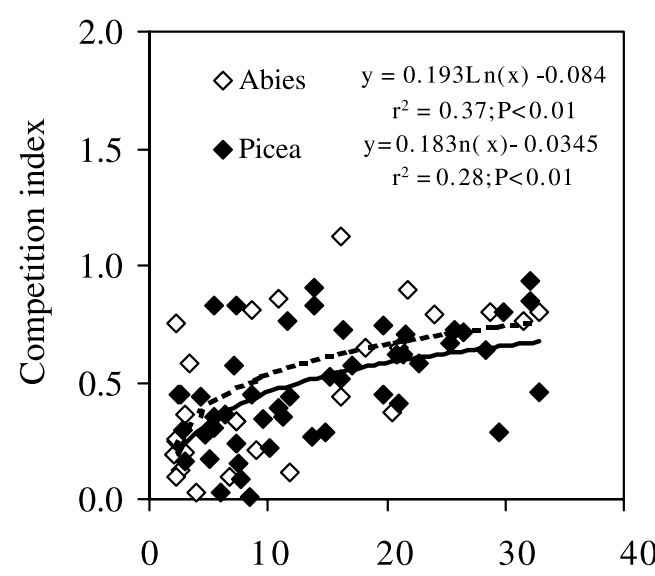

Relative irradiance (\%)

Figure 1. Relationship between relative irradiance and competition index for Norway spruce and silver fir saplings.

The relationships between RHG or ADR and irradiance were significant for each of the last five years $(P<0.05$, data not shown), but the stronger relationships were found with the last three years' average RHG and ADR. This may be explained by the fact that - assuming that during the last three years no significant changes in relative irradiance occurred (no harvest or natural tree falling occurred during this period) - averaging RHG and ADR over this period compensates for the year-toyear or occasional (i.e. affected by insect attack) variations in growth of the apical leader; in five years, on the other hand, light is likely to change even without natural or human-induced tree falling.

The effect of sapling size on crown morphological characteristics apparently depends upon species [10, 33] and is

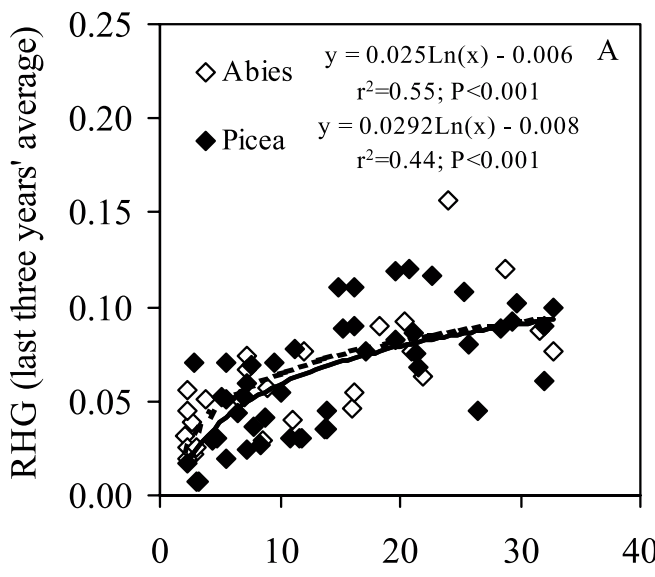

Relative irradiance (\%)

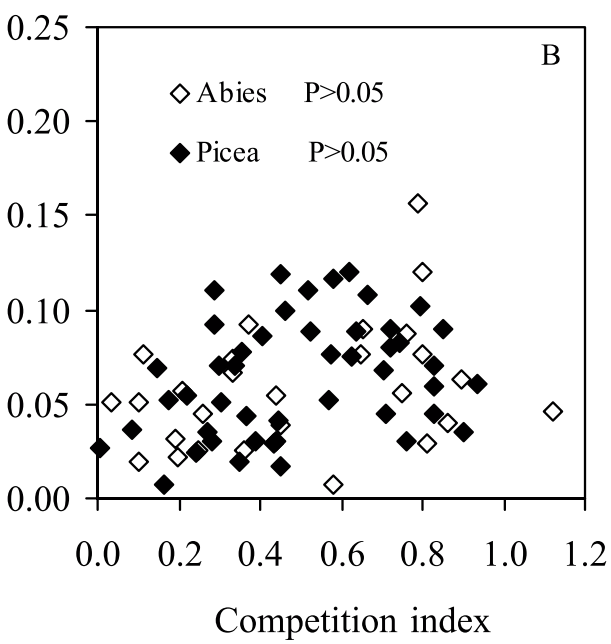

Figure 2. Relationships between relative irradiance (A) or competition index (B) and relative height growth (RHG) of Norway spruce and silver fir saplings. 

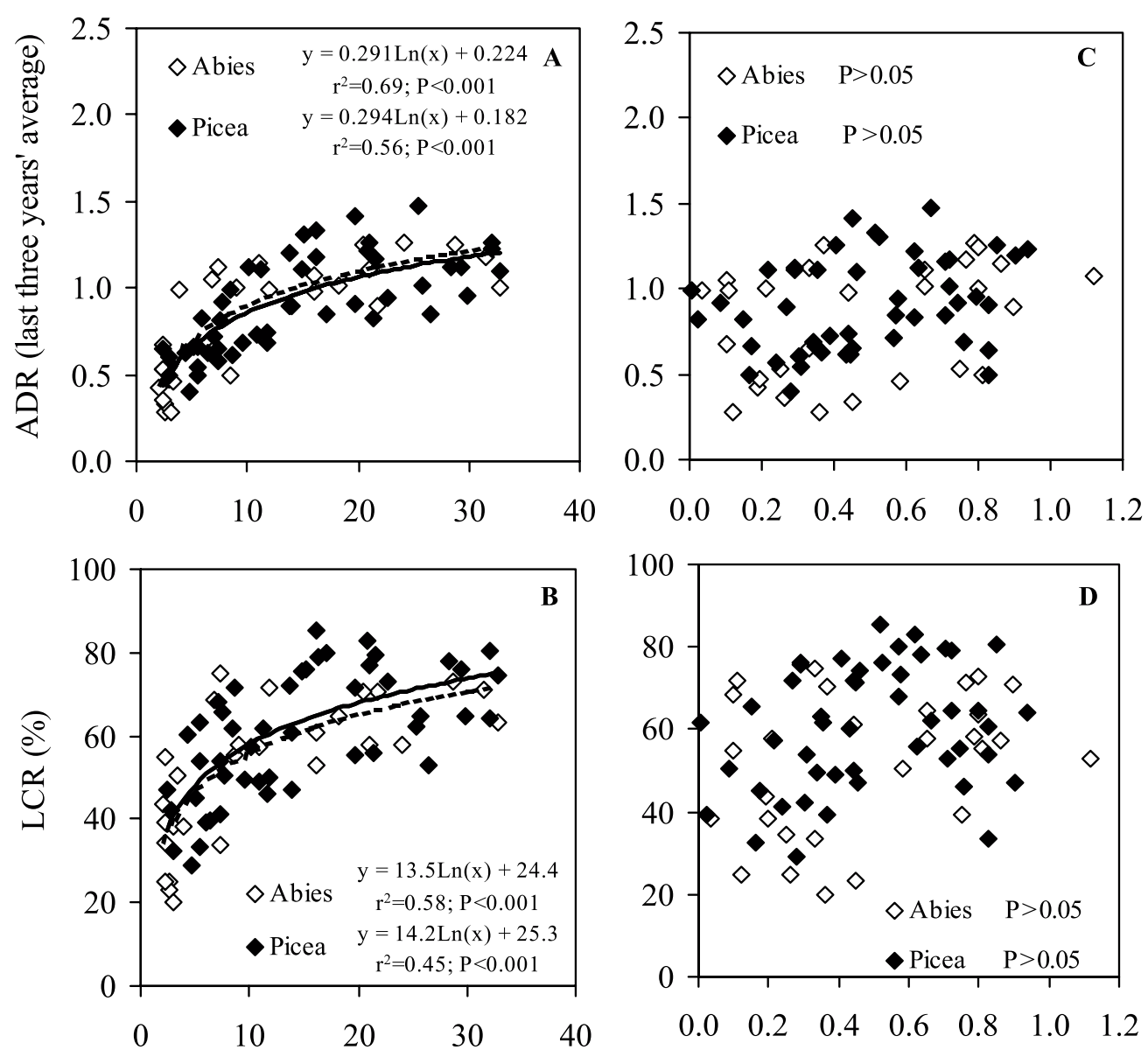

Relative irradiance (\%)

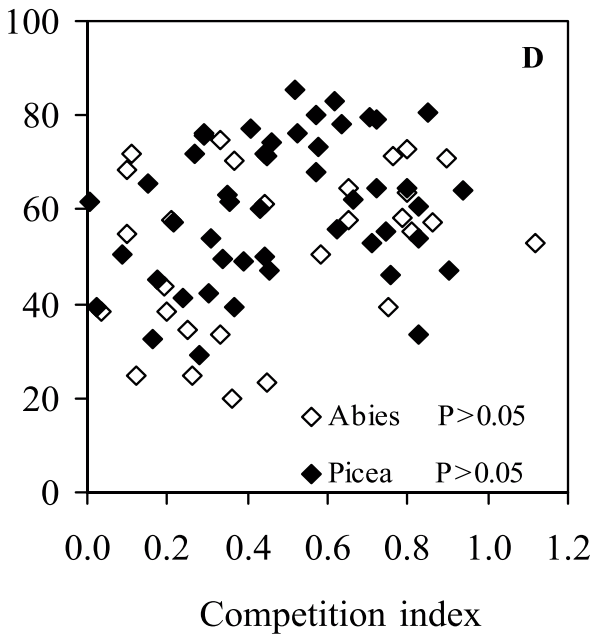

Figure 3. Relationships between relative irradiance (left column) or competition index (right column) and apical dominance ratio (ADR, upper panels) or percent live crown ratio (LCR, lower panels) of Norway spruce and silver fir saplings.

affected by light level [8]. Within the range of irradiance of our study, no significant relationships were found between RHG, ADR or LCR and sapling height $(P>0.05$ in all cases).

Similarly to what found by Duchesneau [10] on balsam fir, below $15 \%$ of relative irradiance LCR was generally lower than $60 \%$, suggesting an important effect of self-pruning in shaded conditions.

The positive effect of relative irradiance on both TPA/SSA and LMA indicates that, in the shoots developed in relatively high light, intercepted PPFD is spread out over more needle surface - and that their needles have more photosynthetic tissue - than in shoots developed in shade [24,30]. Conversely, in the flatter and more sparsely packed shade shoots less self-shading occurs than in shoots that have developed with more light. The overall response which we observed in the saplings grown in the shaded understory - i.e. expanding horizontally at the expense of height growth, lowering the depth of live crown, minimizing the self-shading within the shoot and producing thinner needles - can be viewed as an adaptive strategy to increases light interception, minimize respiration losses and thus maximize carbon gain [12].
These results, while confirming previous observations on the same species $[6,24,25,31]$, indicate no major difference in the plasticity of response to light - at the crown, shoot and needle level - between Norway spruce and silver fir saplings.

The fact that the relationships between the measured parameters (RHG, ADR, LCR, TPA/SSA, LMA) and relative irradiance tended to flatten above 15-20\% of full sunlight, suggests that this value may roughly represent the minimum light threshold for a good growth of both Norway spruce and silver fir saplings in the examined ecological conditions. By using this light value, our results suggest that saplings with $\mathrm{ADR}<1$ and/or LCR $<60 \%$ are likely to be considered light-stressed, confirming the observations by Bagnaresi [2] on same species and by Duchesneau [10] on balsam fir. However, it should be considered that the observed patterns may shift as tree gain in size. LMA, for example, increased with tree size in Picea abies [23], and in mature Abies alba trees it was found to be still responsive to levels of light intensity higher than those measured in our study [6].

Within the range of relative irradiance examined (from $2 \%$ to $32 \%$ ), competition did not significantly affect growth or 

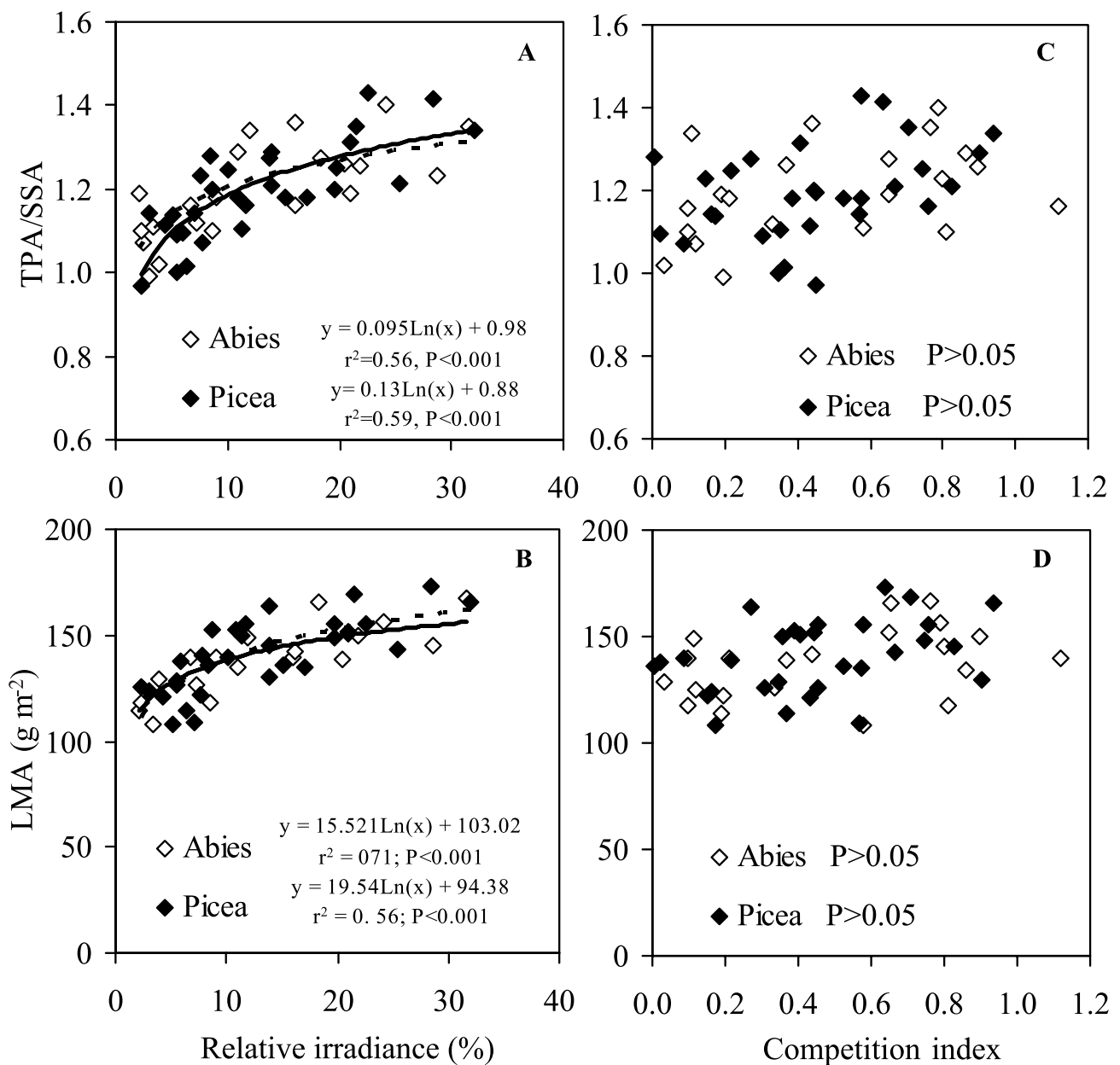

Figure 4. Relationships between relative irradiance (left column) or competition (right column) and total projected needle area divided by shoot silhouette area (TPA/SSA, upper panels) or leaf mass per unit area (LMA, lower panels) of Norway spruce and silver fir saplings.

morphological parameters (Figs. 2B, 3C, 3D, 4C and 4D). As other studies suggested that the effect of competition becomes apparent only in non-limiting light conditions [10,27], we moved to analyze only saplings growing with a relative irradiance higher than $15 \%$. Also in this case, however, the regressions were not statistically significant $(P>0.05$ in all cases). In conclusion, as in the examined forest relative irradiance rarely exceeds 20 $25 \%$ [14], it seems unlikely that competition represents a major factor affecting sapling growth and crown morphology.

Previous studies on the same or similar forests have shown that silver fir saplings are generally more represented in understory environments and less represented in gaps as compared to Norway spruce saplings [15, 20, 28, 29]. This pattern of sapling distribution was observed also on other Picea and Abies spp. [18, 21, 32] and was primarily attributed to a higher morphological plasticity of fir in relation to light. However, as the present study shows that Picea abies and Abies alba have a similar ability to change apical crown morphology, crown depth, shoot and needle morphology along the examined light gradient, we conclude that the ecological differences between these species should be mainly attributable to differences in foliarlevel physiological traits [13], and possibly in allocation patterns, but not to morphological ones.

\section{CONCLUSIONS}

Results of the present study confirm the importance of light on growth and on crown, shoot and needle morphology of Norway spruce and silver fir saplings. In both species, crown morphology varied from a conical and deep crown form in relatively high-light environments to the typical "umbrella" form in the understory shade. Similarly, shoots and needles developed in shade were flatter and with less self-shading than those developed in light. In the examined conditions (relative irradiance ranging from 2 to $32 \%$ ) the effect of competition on growth and morphological parameters was not statistically detectable, although an effect in non-limiting light conditions is possible. On the basis of the present and of previous studies, it is suggested that the ecological differences between Norway spruce 
and silver fir saplings are mainly attributable to differences in physiological traits rather than morphological ones. Among the examined parameters, the last three years' average ADR seems the best and the simplest indicator of the light conditions in which the tree is growing. Our results indicate that a value of $\mathrm{ADR}=1$, corresponding to a relative irradiance of about 15$20 \%$, may be used as a simple threshold to evaluate if a sapling is likely to be considered light-stressed. This parameter is easy to measure and in the examined conditions did not significantly change with sapling height or competition.

Acknowledgements: This paper is dedicated to the late Prof. Umberto Bagnaresi (1927-2003). This study was supported by the European Union, the Forestry Department of the Veneto Region and the Mountain Community of Comelico and Sappada in the framework of the INTERREG PROJECT "Analisi ecologico-strutturale delle foreste in Comelico e Osttirol" (coordinator: Prof. U. Bagnaresi). The authors wish to thank Dr. F. Roffi and F. Pocaterra for help during field measurements and Dr. G. Tonon for helpful comments to the manuscript.

\section{REFERENCES}

[1] Aussenac G., Interactions between forest stands and microclimate: Ecophysiological aspects and consequences for silviculture, Ann. For. Sci. 57 (2000) 287-301.

[2] Bagnaresi U., Baldini E., Rossi F., Energia radiante, struttura ed accrescimento del novellame di abete rosso e di abete bianco in alcune formazioni forestali delle Alpi orientali, Ann. Accad. It. Sci. For. 38 (1989) 81-108.

[3] Bagnaresi U., Giannini R., Grassi G., Minotta G., Paffetti D., Pini Prato E., Proietti Placidi A. M., Stand structure and biodiversity in a mixed, coniferous forest in the eastern Alps, Forestry 75 (2002) 357-364.

[4] Canham C.D., Growth and canopy architecture of shade tolerant trees: response to canopy gaps, Ecology 69 (1988) 86-795.

[5] Carter G.A., Smith W.K., Influence of shoot structure on light interception and photosynthesis in conifers, Plant Physiol. 79 (1985) 1038-1043.

[6] Cescatti A., Zorer R., Structural acclimation and radiation regime of silver fir (Abies alba Mill.) shoots along a light gradient, Plant Cell Env. 26 (2003) 429-442.

[7] Chen H.Y.H., Klinka K., Kayahara G.J., Effects of light on growth, crown architecture and specific leaf area for naturally established Pinus contorta var. latifolia and Pseudotsuga menziesii var. glauca saplings, Can. J. For. Res. 26 (1996) 1149-1157.

[8] Claveau Y., Messier C., Comeau P.G., Coates K.D., Growth and crown morphological responses of boreal conifer seedlings and saplings with contrasting shade tolerance to a gradient of light and height, Can. J. For. Res. 32 (2002) 458-468.

[9] Del Favero R., Lasen C., La vegetazione forestale del Veneto, Libreria Progetto, Padova, 1993.

[10] Duchesneau R., Lesage I., Messier C., Morin H., Effects of light and intraspecific competition on growth and crown morphology of two size classes of understory balsam fir saplings, For. Ecol. Manage. 140 (2001) 215-225.

[11] Gendron F., Messier C., Comeau P.G., Temporal variations in the understorey photosynthetic photon flux density of a deciduous stand: the effects of canopy development, solar elevation, and sky conditions, Agric. For. Meteorol. 106 (2001) 23-40.

[12] Givnish T.J., Adaptation to sun and shade: a whole-plant perspective, Aust. J. Plant Physiol. 15 (1988) 63-92.

[13] Grassi G., Bagnaresi U., Foliar morphological and physiological plasticity in Picea abies and Abies alba saplings along a natural light gradient, Tree Physiol. 21 (2001) 959-967.
[14] Grassi G., Minotta G., Giannini R., Bagnaresi U., The structural dynamics of managed uneven-aged conifer stands in the Italian eastern Alps, For. Ecol. Manage. 185 (2003) 225-237.

[15] Grassi G., Minotta G., Tonon G., Bagnaresi U., Dynamics of Norway spruce and Silver fir natural regeneration in a mixed stand under uneven-aged management, Can. J. For. Res. 34 (2004) 141149.

[16] Jobidon R., Roy V., Cyr G., Net effect of competing vegetation on selected environmental conditions and performance of four spruce seedling stock sizes after eight years in Québec (Canada), Ann. For. Sci. 60 (2003) 691-699.

[17] Kohyama T., Significance of architecture and allometry in saplings, Funct. Ecol. 1 (1987) 399-404.

[18] Kubota Y., Konno Y., Hiura T., Stand structure and growth patterns of understorey trees in a coniferous forest, Taisetsuzan National Park, northern Japan, Ecol. Res. 9 (1994) 333-341.

[19] Kuppers M., Canopy gaps: competitive light interception and economic space filling - a matter of whole plant allocation, in: Caldwell M.M., Pearcy R.W. (Eds.), Exploitation of environmental heterogeneity by plants: ecophysiological processes above- and belowground, Academic Press, San Diego, 1994, pp. 111-144.

[20] Magini E., Ricerche sui fattori della rinnovazione naturale dell'abete bianco sull' Appennino, Ital. For. Mont. 22 (1967) 261270.

[21] Messier C., Doucet R., Ruel J.C., Claveau Y., Kelly C., Lechowicz M.J., Functional ecology of advance regeneration in relation to light in boreal forests, Can. J. For. Res. 29 (1999) 812-823.

[22] Messier C., Nikinmaa E., Effects of light availability and sapling size on the growth, biomass allocation, and crown morphology of understory sugar maple, yellow birch, and beech, Ecoscience 7 (2000) 345-356.

[23] Niinemets Ü., Stomatal conductance alone does not explain the decline in foliar photosynthetic rates with increasing tree age and size in Picea abies and Pinus sylvestris, Tree Physiol. 22 (2002) $515-535$

[24] Niinemets Ü., Kull O., Effects of light availability and tree size on the architecture of assimilative surface in the canopy of Picea abies: variation in needle morphology, Tree Physiol. 15 (1995) $307-315$

[25] Niinemets Ü., Lukjanova A., Needle longevity, shoot growth and branching frequency in relation to site fertility and within-canopy conditions in Pinus sylvestris, Ann. For. Sci. 60 (2003) 195-208.

[26] Oliver D.C., Larson B.C., Forest stand dynamics, McGraw-Hill, 1990, $467 \mathrm{p}$.

[27] Parent S., Messier C., Effects of a light gradient on height growth and crown morphology of balsam fir natural regeneration, Can. J. For. Res. 25 (1995) 878-885.

[28] Piussi P., Alcune osservazioni ed esperienze sulla rinnovazione naturale della picea nella foresta di Paneveggio (Trento), Ann. Acc. It. Sci. For. 14 (1965) 345-400.

[29] Screm E., Studio sulla rinnovazione naturale nei boschi misti di abete e picea di Paularo (Udine), Ann. Acc. It. Sci. For. 16 (1967) 201-251.

[30] Sprugel D.G., J.R. Brooks, Hinckley T.M., Effects of light on shoot geometry and needle morphology in Abies amabilis, Tree Physiol. 16 (1996) 91-98.

[31] Stenberg P., Kangas T., Smolander H., Linder S., Shoot structure, canopy openness, and light interception in Norway spruce, Plant Cell Env. 22 (1999) 1133-1142.

[32] Takahashi K., Plastic response of crown architecture to crowding in understory trees of two co-dominating conifers, Ann. Bot. 77 (1996) 159-164.

[33] Williams H., Messier C., Kneeshaw D.D., Effects of light availability and sapling size on the growth and crown morphology of understory Douglas-fir and lodgepole pine, Can. J. For. Res. 29 (1999) 222-231.

[34] Wright E.F., Coates K.D, Canham C.D., Bartemucci P., Species variability in growth response to light across climatic region in northwestern British Columbia, Can. J. For. Res. 28 (1998) 871-886. 